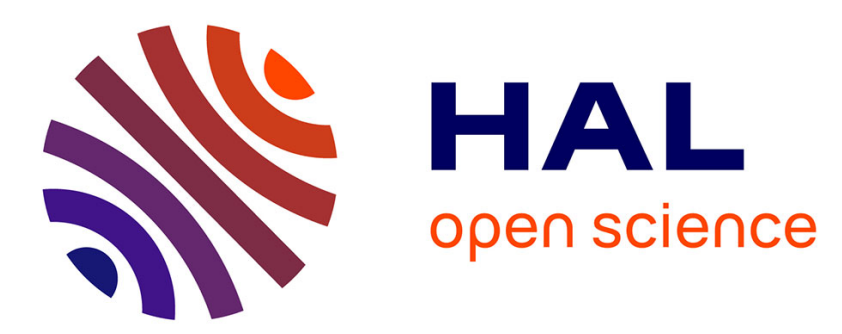

\title{
Two case reports of local envenoming by the Spotted grass snake, Psammophylax rhombeatus (Linnæus, 1758) (Serpentes, Psammophiidae)
}

Ivan Ineich, Francis Girard, Tyrone Ping, Jordy Reynes, Scott A Weinstein

\section{- To cite this version:}

Ivan Ineich, Francis Girard, Tyrone Ping, Jordy Reynes, Scott A Weinstein. Two case reports of local envenoming by the Spotted grass snake, Psammophylax rhombeatus (Linnæus, 1758) (Serpentes, Psammophiidae). Toxicon, 2021, 195, pp.24-28. 10.1016/j.toxicon.2021.02.013 . hal-03273641

\section{HAL Id: hal-03273641 \\ https://hal.sorbonne-universite.fr/hal-03273641}

Submitted on 29 Jun 2021

HAL is a multi-disciplinary open access archive for the deposit and dissemination of scientific research documents, whether they are published or not. The documents may come from teaching and research institutions in France or abroad, or from public or private research centers.
L'archive ouverte pluridisciplinaire HAL, est destinée au dépôt et à la diffusion de documents scientifiques de niveau recherche, publiés ou non, émanant des établissements d'enseignement et de recherche français ou étrangers, des laboratoires publics ou privés. 
1 Two Case Reports of Local Envenoming by the Spotted grass

2 snake, Psammophylax rhombeatus (Linnæus, 1758) (Serpentes,

3 Psammophiidae)

4

5 Ivan Ineich ${ }^{\mathrm{a},{ }^{*}}$, Francis Girard ${ }^{\mathrm{b}}$, Tyrone Ping ${ }^{\mathrm{c}}$, Jordy Reynes ${ }^{\mathrm{d}}$, Scott A.

6 Weinstein $^{\mathrm{e}}$

7

$8 \quad{ }^{a}$ Institut de Systématique, Évolution, Biodiversité (ISYEB)

9 Muséum national d'Histoire naturelle, CNRS, Sorbonne Université, 10 EPHE, Université des Antilles - CP 30, 57 rue Cuvier, 75005 Paris, 11 France

b 167 boulevard Vincent Auriol, 75013 Paris, France

${ }^{c} 7$ Oak Tree Avenue, Glen Anil, KwaZulu-Natal 4051, South Africa

d 31 rue des Mouleyres, 11120 Bize Minervois, France

e Department of Toxinology, Women's and Children's Hospital, 72 


\section{ABSTRACT} accurate medical risk profile for these less-known species.

Keywords:

Non-front fanged snake;

Colubroid;

Psammophiidae;
Two cases of bites by a South African psammophiid snake, Psammophylax rhombeatus, are described and analyzed. These are the first detailed reports of local envenoming by a Psammophylax spp. While handling a wild-collected $1 \mathrm{~m} P$. rhombeatus, the snake inflicted a protracted bite proximal to the metacarpophalangeal joint of digit \#5, left hand of a 24-year-old male amateur herpetologist. Local edema persisted for three days, but no pain or other signs or symptoms including non-specific autonomic effects (e.g. headache, nausea) occurred. In a second case, a 28-year-old male herpetologist-photographer was repositioning a $0.58 \mathrm{~m}$ female $P$. rhombeatus in order to photograph the snake and her egg clutch, when the snake bit the metacarpophalangeal joint of digit \#5, left hand, and briefly advanced its jaws. The bite caused mild local pain, progressive edema of the left hand, and arthralgia; resolution required almost 1 week. Bites from non-front-fanged snakes such as these by $P$. rhombeatus are uncommonly reported in comparison with those described for front-fanged snakes (e.g. Viperidae, Elapidae). Therefore, documentation of bites even with minimal effects provides information essential for the construction of an 
60

61

62

63

64

65

66

Envenoming;

Snake bites;

Psammophylax rhombeatus;

Spotted grass snake;

Rhombic Skaapsteker

\section{Introduction}

Grass Snakes or 'Skaapstekers' (genus Psammophylax Fitzinger, 1843) are terrestrial Central, South and East African non-front-fanged colubroid snakes (NFFCs) with low-pressure venom glands (or, 'Duvernoy glands') (Taub, 1967; Heymans, 1977; McKinstry, 1983). Sub-equal maxillary teeth are followed after a diastema by a pair of slightly enlarged, grooved posterior maxillary teeth. The venom of studied species is reportedly quite viscous, and has been compared with glycerin (FitzSimons, 1921). 60

Six species are recognized in the genus Psammophylax (Table 1). They feed on small vertebrates including fishes (Broadley, 1977; Branch, 1988; Shine et al., 2006; Cottone \& Bauer, 2010; Chippaux \& Jackson, 2019; Keates et al., 2019; Wilkey, 2019). They are unusual among snakes by variably engaging in parental care (Shine et al., 2006). Their common name 'Skaapsteker' has an Afrikaans origin 
related to their presumed habit of biting sheep (literally: 'sheep stabber'), a belief that unfortunately leads some ranchers to kill these snakes on sight (Tyrone Ping, personal observations). However, cape cobras (Naja nivea (Linnæus, 1758), Elapidae) are probably responsible for most of the stock losses that are blamed on relatively harmless Psammophylax (FitzSimons, 1921; Alexander \& Marais, 2007), although some authors have considered puff adders, Bitis arietans Merrem, 1820 (Viperidae), more likely culprits (Elstob in Chippaux \& Jackson, 2019).

Early workers, most prominently, Frei (1910), Andrews (1912) and FitzSimons (1912) contemplated whether Psammophylax spp. were venomous. Based on experiments with fowl reportedly bitten by Trimerorhinus rhombeatus (most likely P. rhombeatus; Trimerorhinus A. Smith, 1847 is a junior synonym of Psammophylax.), FitzSimons (1921: 488) considered the possibility that this species could be as dangerous as the Boomslang (Dispholidus typus (A. Smith, 1828)) and its venom more potent than that of elapid species of notable medical importance (e.g., cobras, Naja spp. and mambas, Dendroaspis spp.). However, Phisalix (1922) reported delayed lethal effects in a small sampling of rodents and chicken bitten by specimens of two Psammophylax species from South Africa.

\section{9}

Christensen (1955: 2) later commented that Trimerorhinus tritaeniatus possess “potent venom”. Alexander and Marais (2007) 
stated that the venom of Psammophylax spp. has no medical relevance. Spawls et al. (2018) suggested that the venom of Psammophylax spp. is "fairly toxic", but little is injected when a bite is delivered to a human, and thus no serious symptoms have been recorded. Wilkey (2019) considered the two species of Psammophylax present in Malawi and reported that their venom is mild and may cause local swelling and some mild pain. However, Spawls and Branch (2020) noted that $P$. tritaeniatus reportedly have "toxic venom" with that of $P$. rhombeatus having "potent" neurotoxicity. Nonetheless, they concluded that no medically significant effects from a Psammophylax bite have so far been recorded. Likewise, FitzSimons and Smith (1958) noted the absence of any reported serious case of human envenomation from Trimerorhinus (now Psammophylax), and opined that all published cases are dubious. Consistent with the latter impression, Chapman (1968) described the effects observed in three cases of bites by Psammophylax spp. in Natal, and indicated that these consisted of "a slight local reaction of bruising and swelling, one with a rigor". Branch (1982) reported similar signs and symptoms following a bite from an East Cape $P$. rhombeatus. However, these reports are described second hand and it is not clear if formal medical review was ever conducted within a reasonable timeframe after the bites.

Warrell (1995: 460) noted that $P$. tritaeniatus bites were associated with non-specific systemic symptoms such as nausea, 
117 headache and rigors. Warrell (2010) later opined that Psammophylax 118 is probably capable of mild envenomations that cause only local pain, 119 mild swelling and lymphangitis, and emphasized the absence of any 120 reported serious bites. Kuch and Mebs (2002, 167-168) quoted 121 FitzSimons (1910) apparently referring to a case of human 122 envenomation from $P$. rhombeatus that reportedly included "giddiness, lassitude, cold clammy skin, cold sweat on the forehead, a little swelling at the site of the fang punctures, with discolouration of the surrounding tissue".

The previously reported cases were also reviewed by Minton bites and their reported effects.

While performing field work and photography, two of the authors were bitten by specimens $P$. rhombeatus and developed effects consistent with local envenoming. We report here on these two first-hand cases of bites by $P$. rhombeatus, present the details of these 


\section{Case 1}

While performing a herpetological field survey on September 30 2004 near the Sterkfontein dam (Orange Free State) in South Africa $\left(28^{\circ} 27^{\prime} \mathrm{N}, 2^{\circ} 01^{\prime} \mathrm{E}\right)$ in the morning around $1000-1100 \mathrm{hrs}$, one of us (JR; 24 yr old male, amateur herpetologist, with no significant medical history, no current medications or known allergies) was bitten by an approximately $1 \pm \mathrm{m}$ (total length) $P$. rhombeatus (gender undetermined) (Fig. 1). The victim was previously (2002) bitten by a Brazilian lancehead, Bothrops moojeni Hoge, 1966 (Viperidae, Crotalinae) and severely envenomed (progressive edema and consumptive coagulopathy); he was treated with six vials of Bothrofav $^{\circledR}$ (Sanofi-Pasteur, Lyon, France; a monovalent F(ab’) antivenom against venom of the fer-de-lance or Martinique lancehead, Bothrops lanceolatus Bonnaterre, 1790; this antivenom has no clinically proven paraspecificity for $B$. moojeni venom).

The $P$. rhombeatus was discovered under a piece of pottery (pipe) in a humid habitat that had recently burned (2-3 months prior) and was beginning to reestablish floral growth. The snake was captured without difficulty, and was kept for several minutes in order to photograph the specimen. While handling the snake, the victim momentarily loosened his grip, and was promptly bitten proximal to 
the metacarpophalangeal joint of the digit \#5, left hand. The snake maintained a firm grip for approximately 10-15 secs while it implanted the enlarged posterior maxillary teeth into the victim's hand. Once manually disengaged from the bite site, two symmetrical puncture marks consistent with the enlarged posterior maxillary teeth, as well as small blood drops produced by several of the anterior teeth were observed (Fig. 2). The local, proportional bleeding stopped after several minutes. There was no first aid applied, and the wound was not disinfected. Several minutes post-bite, edema and erythema were first noted around the bite site. Within about seven hours post-bite, the edema involved the whole hand; moving the hand and fingers was not painful, but there was a nearly complete limitation of flexion and extension; manual dexterity was significantly affected (e.g., handling silverware was very difficult). Subsequently, the local edema of the bitten hand remained unchanged for three days and resolved on only the fourth day post-bite. The pain was estimated as 1/10 (using the verbal pain 0 to 10 with 10 being 'unbearable' pain) during the bite, but there was no pain (0/10), even when moving the hand and fingers. The victim described the most persistent effect as marked digital stiffness noted especially with attempted flexion of the fingers. Ecchymosis was absent and there were no other symptoms or signs including non-specific complaints such as headache and/or nausea. Complete resolution was observed within 4 days. 
A 28-yr-old male herpetologist/professional photographer with

194

195

196

197

198

199

200

201

202

203

204

205

206

207

208

209

210

211

212

213

214

215

216

no significant medical history or allergies was investigating the herpetofauna at Glen Austen Gauteng, South Africa $\left(25.975536^{\circ} \mathrm{N}\right.$, $28.169737^{\circ} \mathrm{E}$ ) at $1120 \mathrm{hrs}$ on October 182014 when he encountered an approximately $600 \mathrm{~mm}$ (total length) female $P$. rhombeatus, that was coiled around a recently deposited egg clutch (Fig. 3A). The snake was gently moved in order to photograph the eggs, together with the specimen. As the snake was handled, it inflicted a bite delivered to the medial-dorsal surface of the thumb, left hand, that initially consisted of contact with only the anterior maxillary and mandibular teeth; however, the snake began to advance its jaws and the victim sensed being punctured by both of the enlarged posterior maxillary teeth (Fig. 3B). The snake was firmly attached and resisted removal by the victim; it was gently coaxed to release by manually manipulating its head and had remained attached for approximately 45 seconds. The victim noted that immediately after detachment of the snake, the wounds immediately bled and continued bleeding for an estimated 2-3 minutes; the victim opined that the wounds bled a bit disproportionally in relation to the lacerations and punctures comprising the wound site. There was no attempted first-aid or interventions for the bite. For several hours post-bite, the victim only noted a "slight burning sensation", but approximately 7 hours later the victim reported being awakened by his partner who stated that she felt "heat radiating" from his hand. The victim noted local moderate 
217 edema that involved the entire left hand; the edema mildly inhibited 218 digit flexion/extension and the skin was notably warm ("hot to 219 touch"). The victim reported a mild "throbbing-type pain" ranked 2/10 220 ("very mild, but pulsating, making it uncomfortable particularly when 221 trying to sleep"), and did not ingest any analgesics or any other 222 medications/substances. The edema was still present and moderately 223 inhibited manual dexterity 36 hours post-bite (Figs 4A, 4B), and 224 persisted for almost 1 week. Stiffness was present in the all of the 225 metacarpophalangeal joints and digits of the left hand, but this completely subsided after approximately 4 days. Thereafter, the signs and symptoms fully resolved without any sequelae. The victim reported several previous asymptomatic and uneventful brief bites 229 from several species of non-front-fanged snakes including Psammophylax (also, the psammophiids, short-snouted grass snake, Psammophis brevirostris Peters, 1881; cross-marked grass snake, Psammophis crucifer (Daudin, 1803), and the colubrine colubrid, marbled tree snake, Dipsadoboa aulica (Günther, 1864)); there was no history of any envenoming from any front-fanged species, and no history of having received antivenom. The victim has many years of experience photographing reptiles in the field often requiring close contact with many species of reptiles. 
The victims in these cases received firm bites with some jaw advancement from adult $P$. rhombeatus. Although the snakes were attached for $<1 \mathrm{~min}$, both victims developed mild-moderate signs and symptoms consisting of significant local edema with some local progression and minimal pain at the bite site. These resolved without sequelae in four to seven days (respectively, victims \#1 and \#2). Notably, both victims experienced similar clinical evolution of edema and local pain. The victims did not receive formal medical review and this limits the evidence quality (Level C/D, following the evidence rankings by Weinstein et al. (2011). However, careful observations were recorded and accurately correlated with images taken in chronological order, thus providing precise records of the effects of the bites.

\section{Observations of Psammophylax spp. have suggested that these} snakes rarely attempt to bite unless roughly handled (FitzSimons, 1921). Our own observations (FG, TP) suggest that some $P$. rhombeatus specimens are quick to bite when handled, as was also reported by Branch (1988). However, the effects of the bites described here may indicate that an especially prolonged bite by a large adult specimen might produce more significant local envenoming. Spawls and Branch (2020) commented that $P$. rhombeatus, "has a potent neurotoxic venom, but no adverse symptoms ever recorded from a bite", while Bates (1996) referring to Psammophylax venom and that of several other NFFC stated, “...is comparatively weak and bites 
usually result in only localized swelling and pain similar to that

267

268

269

270

271

272

273

274

275

276

277

278

279

280

281

282

283

284

285

286

287

288

289

290

caused by a bee sting". Perceived venom neurotoxicity of

Psammophylax is probably based on the previously outlined

experiments by Phisalix (1922), FitzSimons (1921), and the comments

by Christensen (1955). However, there is so far no biomedical

evidence of neurotoxins in any Psammophylax venom, nor any

clinical evidence of neurotoxicity from their bites, although as noted

here, detailed reports about their venom and bites are absent in the

literature. Therefore, there is insufficient documentation to firmly

characterize the clinical syndrome that may be caused by prolonged

bites by Psammophylax. Additionally, 3-finger-fold neurotoxins are

common in many NFFCs including other psammophiids (Lumsden et

al., 2007; Jackson et al., 2019; Modahl and Mackessy, 2019), and

these may occur in Psammophylax venoms, but could have prey

specificity (e.g., lizards). We decline speculation about the venom

components that may have caused the effects that developed in the victims described here. Several venom components probably

contribute to this e.g., snake venom metalloproteases; however, victim

hypersensitivity may also play a role in the acute effects of some

NFFC bites such as these (Weinstein et al., 2011). The minimal pain

associated with the rapidly progressive edema suggests the specific investigation of this whenever possible e.g., laboratory evaluation of inflammatory cellular subsets and immunoglobulins. For example, Th2-related markers, including the interleukins (IL) and C-motif chemokines (CCL): IL-5, IL-13, IL-10, IL-31, CCL13, CCL18, and 
many others, are prominently expressed in lesions manifested in acute

292

293

294

295

296

297

298

299

300

301

302

303

304

305

306

307

308

309

310

311

312

313 atopic dermatitis (Malik et al., 2017).

Management of bites by Psammophylax spp. is governed by the severity of the victim's distress; simple wounds and local effects can be managed with meticulous wound care, while progressive edema, persistent pain, bleeding and greater distress suggestive of systemic effects should be promptly reviewed by a physician whenever possible. There is no antivenom for bites by Psammophylax spp. and no antivenom of any kind should be given because: it subjects the patient to unnecessary risks; it would be ineffective, and in any case is not clinically indicated. There is also no evidence supporting the administration of parenteral steroids, or antihistamines for treatment of bites by NFFC, nor for antibiotic prophylaxis unless there has been interference with the wound (e.g., incorrect first-aid, application of local remedies, etc.), environmental contamination, or shows signs of early necrosis (Weinstein et al., 2011; Weinstein, 2017).

Further studies of the venoms of Psammophylax spp. are desirable, and formal reports of any bites inflicted by these snakes can further document their medical effects and clinical management. 
315 Alexander, G., Marais, J. 2007. A guide to the Reptiles of Southern 316 Africa. Struik Publishers, Cape Town, South Africa. 408 pp.

318 Andrews, W.H. 1912. Experiments with snakes. Report Director Vet. 319 Res., Dept. Agric., Union of S. Africa 2, 406-483.

321 Bates, M.F. 1995. Poisonous snakes of the Free State. Culna 49, 1232214.

Branch, B. 1988. Field Guide to the Snakes and Other Reptiles of Southern Africa (First edition). New Holland, London. 328 pp. + 96 326 pls.

327

Branch, B. 2005. A photographic guide to snakes and other reptiles and amphibians of East Africa. Struik Publishers, Cape Town, South Africa. 144 pp.

332 Branch, W.R. 1982. Venomous snakes of southern Africa, 3. 333 Concluding part: Colubridae. The Snake 14, 1-17.

335 Branch, W.R., Baptista, N., Keates, C., Edwards, S. 2019. 336 Rediscovery, taxonomic status, and phylogenetic relationships of two 337 rare and endemic snakes (Serpentes: Psammophiinae) from the 338 southwestern Angolan plateau. Zootaxa 4590, 342-366. 
340 Branch, W.R., Braak, H.H. 1987. Reptiles and amphibians of the 341 Addo Elephant National Park. Koedoe 30, 61-111.

343 Broadley, D.G. 1977. A revision of the African snakes of the genus Psammophylax Fitzinger (Colubridae). Occas. Pap. Natl. Mus. Rhod., Ser. B 6(1), 1-44.

Chapman, D.S. 1968. The symptomatology, pathology, and treatment of the bites of venomous snakes of central and southern Africa. Bücherl, W., Buckley, E.E., Deulofeu, V., eds. Venomous Animals and Their Venoms. Vol. I: Venomous vertebrates. Academic Press, New York, 463-527.

Chippaux, J.-P., Jackson, K. 2019. Snakes of Central and Western Africa. Johns Hopkins University Press, Baltimore. $x+429$ pp.

Christensen, P.A. 1955. South African snake venoms and antivenoms. The South African Institute for Medical Res., Johannesburg, v, 129 pp.

Cottone, A.M., Bauer, A.M. 2010. Sexual dimorphism, diet, reproduction, and their geographic variation in sympatric Psammophiids, Psammophis crucifer and Psammophylax rhombeatus rhombeatus, from Southern Africa. Copeia 4, 578-590. 
FitzSimons, F.W. 1910. The Snakes of South Africa; Their Venom and the Treatment of Snake Bite. Walton, Port Elizabeth, South Africa. $160 \mathrm{pp}$.

FitzSimons, F.W. 1912. The snakes of Southern Africa: Their Venom and Treatment of Snake Bite. T.M. Miller, Cape Town, South Africa. $371547 \mathrm{pp}$.

FitzSimons, F.W. 1921. The snakes of South Africa, their venom and 374 the treatment of snake bite. T. Maskew Miller, Cape Town. xvi +550 375 pp.

FitzSimons, D.C., Smith, H.M. 1958. Another rear-fanged South African snake lethal to humans. Herpetologica 14, 198-202.

380 Frei, W. 1910. Über einige Experimente mit Giften und 381 Speicheldrüsenextracten südafrikanischer Schlangen. Zeitschr. Hyg. 382 Infektionskr. 3, 211-217

Heymans, J.C. 1977. Variations des glandes parotidiennes chez les Serpents Colubridae d'Afrique Centrale. Rev. Zool. Afr. 91, 893-905. 
390 Keates, C., Conradie, W., Greenbaum, E., Edwards, S. 2019. A snake 391 in the grass: Genetic structuring of the widespread African grass snake 392 (Psammophylax Fitzinger 1843), with the description of a new genus 393 and a new species. J. Zool. Syst. Evol. Res. 57, 1039-1066. 394

Kuch, U., Mebs, D. 2002. Envenomations by colubrid snakes in 396 Africa, Europe and the Middle East. J. Toxicol. - Toxin Reviews 21, 397 $159-179$.

398

399

Lumsden, N.G., Banerjee, Y., Kini, R.M., Kuruppu, S., Hodgson, 400 W.C. 2007. Isolation and characterization of rufoxin, a novel protein 401 exhibiting neurotoxicity from venom of the psammophiine, Rhamphiophis oxyrhynchus (Rufous beaked snake).

403 Neuropharmacology 52, 1065-1070. doi:

404 10.1016/j.neuropharm.2006.11.002

405

Malik, K., Heitmiller, K.D., Czarnowicki, T. 2017. An update on the 407 pathophysiology of atopic dermatitis. Dermatol. Clin. 35(3), 317-326.

408

409 McKinstry, D.M. 1983. Morphologic evidence of toxic saliva in 410 colubrid snakes: a checklist of world genera. Herpetological Review $411 \quad 14,12-15$. 
413 Minton, S.A., Jr. 1990. Venomous bites by nonvenomous snakes: an 414 annotated bibliography of colubrid envenomation. J. Wild. Med. 1(2), $415 \quad 119-127$.

417 Modahl, C., Mackessy, S.P. 2019. Venoms of rear-fanged snakes: 418 New proteins and novel activities. Front. Ecol. Evol. 7 (doi: 419 10.3389/fevo.2019.00279).

421 Phisalix, M. 1922. Animaux venimeux et venins : la fonction 422 venimeuse chez tous les animaux ; les appareils venimeux, les venins et leurs propriétés ; les fonctions et usages des venins ; l'envenimation et son traitement. Tome 2. Masson \& Cie Éditeurs - Libraires de l'Académie de Médecine, Paris. xii + 864 pp. + [1 p., errata], 17 pls. Shine, R., Branch, W.R., Webb, J.K., Harlow, P.S., Shine, T. 2006. Sexual dimorphism, reproductive biology, and dietary habits of 429 Psammophiine snakes (Colubridae) from Southern Africa. Copeia $430 \quad 2006,650-664$.

432 Spawls, S., Branch, B. 2020. The Dangerous Snakes of Africa. 433 Bloomsbury, London (Oxford, New York, New Dehli, Sydney). 336 434 pp. 
Spawls, S., Howell, K., Hinkel, H., Menegon, M. 2018. Field Guide to

437 East African Reptiles, 2nd edition. Bloomsbury Wildlife, London. 624 438 pp.

439

Taub, A.M. 1967. Comparative histological studies on Duvernoy's

441 gland of Colubrid snakes. Bull. Amer. Mus. Nat. Hist. 138, 1-50, 58

442 plates.

443

444

Warrell, D.A. 1995. Clinical toxicology of snakebite in Africa and the 445

Middle East / Arabian Peninsula. In Meier, J., and White, J. Handbook

446 of clinical toxicology of animal venoms and poisons. CRC Press,

447 Boca Raton, New York, London, Tokyo.

448

449

Warrell, D.A. 2010. Guidelines for the prevention and clinical 450 management of snakebite in Africa. World Health Organization, 451 Regional Office for Africa, Brazzaville. xiv + 129 pp.

452

453

Weinstein, S.A. 2017. Non-Front-Fanged Colubroid Snakes. In Brent, 454 J., Burkhart, K., Dargan, P., Hatten, B. et al. Textbook of Critical 455 Care Toxicology. Springer International, pp. 2453-2492.

457 Weinstein, S., Warrell, D., White, J., Keyler, D.E. 2011. "Venomous" 458 Bites from Non-Venomous Snakes. 1st Edition. A Critical Analysis of 
459 Risk and Management of "Colubrid" Snake Bites. Elsevier, London. $460 \quad$ xxvii $+336 \mathrm{pp}$.

461

462 Wilkey, R. 2019. Snakes of Malawi. A field guide to the snake species 463 of Malawi (2019 revised edition, 5th revision). Biddles Books. 329 pp. 464 
A brief inventory of Psammophylax spp. and related species.

\begin{tabular}{|c|c|c|c|c|}
\hline \multirow[b]{2}{*}{$\begin{array}{c}\text { Valid name } \\
\text { Psammophylax kellyi } \\
\text { Conradie, Keates \& } \\
\text { Edwards in Keates, } \\
\text { Conradie, Greenbaum \& } \\
\text { Edwards, } 2019 \\
\end{array}$} & Common names & Previous name(s); subspecies & Distribution & Reference(s) \\
\hline & $\begin{array}{l}\text { Tanzanian Grass } \\
\text { Snake, Tanzanian } \\
\text { Skaapsteker }\end{array}$ & $\begin{array}{l}\text { Psammophylax multisquamis } \\
\text { [pro parte]; [no recognized } \\
\text { subspecies] }\end{array}$ & $\begin{array}{l}\text { Mount Meru, N } \\
\text { Tanzania }\end{array}$ & Keates et al., 2019 \\
\hline $\begin{array}{c}\text { Psammophylax } \\
\text { multisquamis } \\
\text { (Loveridge, 1932) }\end{array}$ & $\begin{array}{l}\text { Kenyan Grass Snake, } \\
\text { Kenyan Striped } \\
\text { Skaapsteker }\end{array}$ & $\begin{array}{c}\text { Trimerorhinus tritaeniatus } \\
\text { multisquamis, Psammophylax } \\
\text { tritaeniatus multisquamis, } \\
\text { Psammophis variabilis } \\
\text { multisquamis } ; \text { [no recognized } \\
\text { subspecies] }\end{array}$ & $\begin{array}{l}\text { Ethiopia, Kenya, N } \\
\text { Tanzania, N Rwanda }\end{array}$ & $\begin{array}{c}\text { Branch, 2005; } \\
\text { Spawls et al., 2018; } \\
\text { Chippaux \& } \\
\text { Jackson, } 2019\end{array}$ \\
\hline $\begin{array}{l}\text { Psammophylax ocellatus } \\
\text { (Bocage, 1873) }\end{array}$ & $\begin{array}{l}\text { Angolan Grass } \\
\text { Snake, Angolan } \\
\text { Skaapsteker }\end{array}$ & $\begin{array}{c}\text { Psammophylax rhombeatus } \\
\text { ocellatus [pro parte]; [no } \\
\text { recognized subspecies] }\end{array}$ & $\begin{array}{l}\text { SW Angola, ?NW } \\
\text { Namibia }\end{array}$ & $\begin{array}{l}\text { Branch et al., 2019; } \\
\text { Keates et al., } 2019\end{array}$ \\
\hline $\begin{array}{c}\text { Psammophylax } \\
\text { rhombeatus (Linnæus, } \\
1758 \text { ) }\end{array}$ & $\begin{array}{l}\text { Spotted Grass Snake, } \\
\text { Spotted Skaapsteker, } \\
\text { Rhombic Skaapsteker }\end{array}$ & $\begin{array}{l}\text { Coluber rhombeatus, } \\
\text { Trimerorhinus rhombeatus, } \\
\text { Psammophylax rhombeatus } \\
\text { ocellatus [pro parte]; [no } \\
\text { recognized subspecies] }\end{array}$ & $\begin{array}{l}\text { S Namibia, Rep. of } \\
\text { South Africa, Lesotho, } \\
\text { Swaziland, SW Angola }\end{array}$ & $\begin{array}{l}\text { Phisalix, 1922; } \\
\text { Branch, 1988; } \\
\text { Alexander \& Marais, } \\
\text { 2007; Chippaux \& } \\
\text { Jackson, 2019; } \\
\text { Spawls \& Branch, } \\
2020 \\
\end{array}$ \\
\hline $\begin{array}{c}\text { Psammophylax } \\
\text { tritaeniatus (Günther, } \\
\text { 1868) }\end{array}$ & $\begin{array}{l}\text { Striped Grass Snake, } \\
\text { Striped Skaapsteker, } \\
\text { Three-lined Grass } \\
\text { Snake }\end{array}$ & $\begin{array}{l}\text { Trimerorhinus tritaeniatus, } T . \\
\text { tritæniatus, Rhagerrhis } \\
\text { tritaeniatus, Rhagerhis } \\
\text { tritaeniata; } \text { [recognized } \\
\text { subspecies: } P \text {. t. tritaeniatus, } P . \\
\text { t. subniger] }\end{array}$ & $\begin{array}{l}\text { NE Namibia, N } \\
\text { Botswana, Zimbabwe, } \\
\text { NE Rep. of South } \\
\text { Africa, Angola, S } \\
\text { Tanzania, Zambia, } \\
\text { Malawi, S Dem. Rep. } \\
\text { Congo, Zambia, } \\
\text { Mozambique }\end{array}$ & $\begin{array}{c}\text { Phisalix, 1922; } \\
\text { Branch, 1988, 2005; } \\
\text { Alexander \& Marais, } \\
\text { 2007; Spawls et al., } \\
\text { 2018; Chippaux \& } \\
\text { Jackson, 2019; } \\
\text { Wilkey, 2019; } \\
\text { Spawls \& Branch, } \\
\text { 2020 }\end{array}$ \\
\hline $\begin{array}{c}\text { Psammophylax } \\
\text { variabilis Günther, } 1893\end{array}$ & $\begin{array}{l}\text { Grey-bellied Grass } \\
\text { Snake, Grey-bellied } \\
\text { Skaapsteker }\end{array}$ & $\begin{array}{c}\text { Trimerorhinus tritaeniatus [pro } \\
\text { parte], Trimerorhinus } \\
\text { tritaeniatus. variabilis; } \\
\text { [recognized subspecies: } \\
\text { P.v.variabilis, P.v. vanoyei] }\end{array}$ & $\begin{array}{l}\text { N Botswana, Dem. } \\
\text { Rep. Congo, Tanzania, } \\
\text { Burundi, Rwanda, } \\
\text { Uganda, Kenya, } \\
\text { Ethiopia, Malawi, } \\
\text { Zambia, Mozambique, } \\
\text { Namibia } \\
\end{array}$ & $\begin{array}{c}\text { Branch, 1988; } \\
\text { Alexander \& Marais, } \\
\text { 2007; Spawls et al., } \\
\text { 2018; Chippaux \& } \\
\text { Jackson, 2019; } \\
\text { Wilkey, 2019 }\end{array}$ \\
\hline $\begin{array}{l}\text { Kladirostratus acutus } \\
\text { (Günther, 1888) }\end{array}$ & $\begin{array}{l}\text { Striped Beaked } \\
\text { Snake, Beaked } \\
\text { Skaapsteker }\end{array}$ & $\begin{array}{c}\text { Psammophis acutus; } \\
\text { Psammophylax acutus; } \\
\text { Rhamphiophis acutus; } \\
\text { [recognized subspecies : K. a. } \\
\text { acutus, K. a. jappi] } \\
\end{array}$ & $\begin{array}{c}\text { Angola, NW/W } \\
\text { Zambia, S Dem. Rep. } \\
\text { Congo, W Tanzania, N } \\
\text { Malawi, N Rwanda }\end{array}$ & Keates et al., 2019 \\
\hline $\begin{array}{l}\text { Kladirostratus togoensis } \\
\text { (Matschie, 1893) }\end{array}$ & $\begin{array}{c}\text { Northern Sharp- } \\
\text { nosed Skaapsteker }\end{array}$ & $\begin{array}{c}\text { Psammophis togoensis; } \\
\text { Rhamphiophis togoensi; } \\
\text { Rhamphiophis acutus } \\
\text { garambensis; Psammophylax } \\
\text { acutus togoensis; } \\
\text { Psammophlylax togoensis; [no } \\
\text { recognized subspecies] }\end{array}$ & $\begin{array}{l}\text { Ghana, Togo, Nigeria, } \\
\text { Cameroon, Central } \\
\text { Afr. Rep., N Dem. } \\
\text { Rep. Congo, Uganda }\end{array}$ & Keates et al., 2019 \\
\hline
\end{tabular}


$471 \quad$ Figure 1. The Spotted Grass Snake or Rhombic Skaapsteker

472 (Psammophylax rhombeatus) that inflicted the bite (Case \#1). The

473 snake was approximately $1 \mathrm{~m}$ total length; gender is unknown.

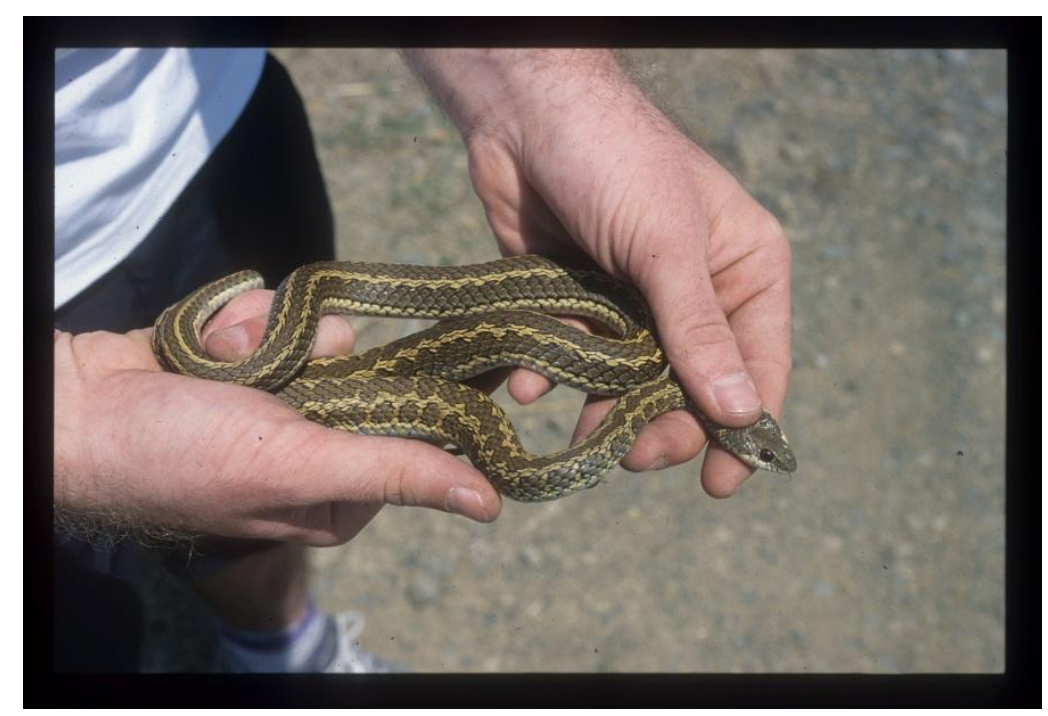


478 Figure 2. The left hand shortly after having been bitten by 479 Psammophylax rhombeatus (Case \#1). The snake remained attached 480 for approximately 10-15 seconds, but did not advance its jaws. The 481 bite produced symmetrical punctures that corresponded with the 482 enlarged posterior maxillary teeth; only scant bleeding was noted. 483 Note the early edema proximal to the metacarpophalangeal joint.

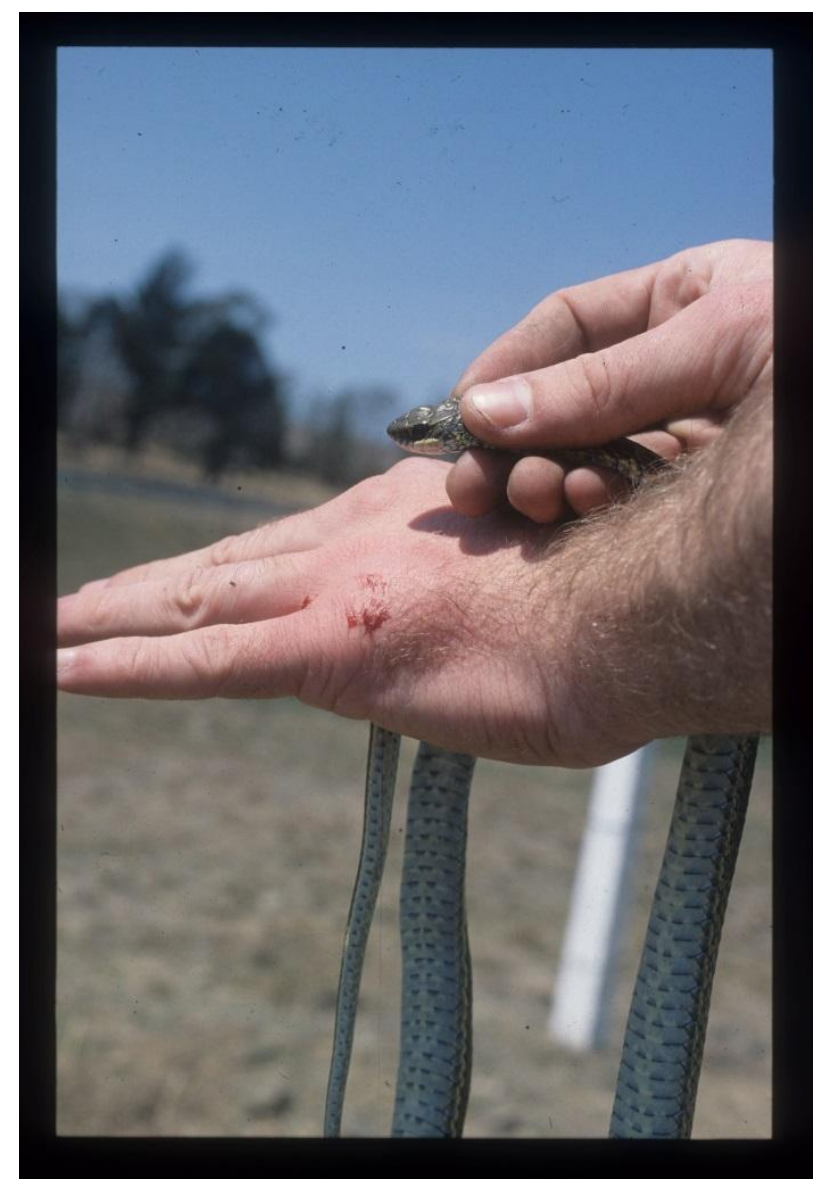


489

490

491

492

493

494

495

496

497

498

499

500

501

502

503

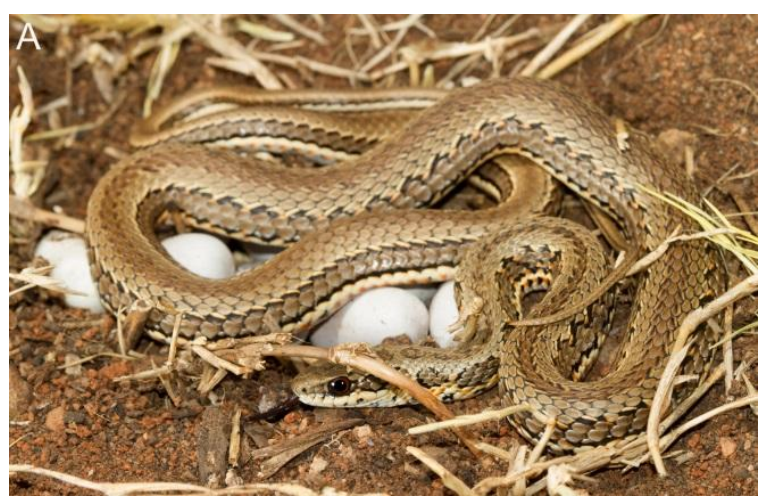
(image courtesy of Tyrone Ping).

Figures 3A, B. (A) The Spotted Grass Snake or Rhombic Skaapsteker (Psammophylax rhombeatus) that inflicted the bite (Case \#2). The snake (female) was approximately $580 \mathrm{~mm}$ total length, and was found coiled around her clutch of recently deposited eggs. The snake inflicted the bite when she was re-positioned in order to take photographs (image courtesy of Tyrone Ping). (B) The Psammophylax rhombeatus specimen shown in Fig. 3A, inflicting the bite on the medial-dorsal surface of the left thumb, victim \#2. The wound reportedly bled "freely", but bleeding ceased within approximately 2 minutes. The victim reported that the subsequent local edema was accompanied only by mild throbbing pain, but rendered sleep difficult

504

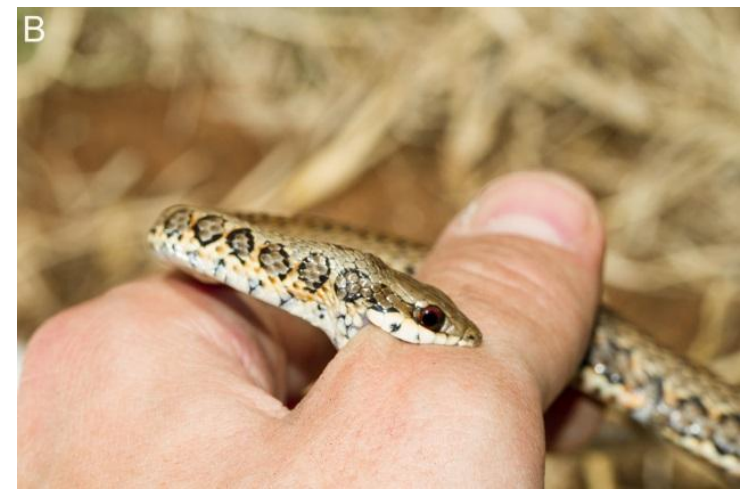

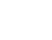


507 Figures 4A, B. Persistent local effects, left hand 36 hrs after bite by

508 Psammophylax rhombeatus on medial-dorsal surface of left thumb

509 (Case \#2). The snake remained attached for approximately 45 seconds

510 and briefly advanced its jaws. The bite caused progressive local

511 edema that eventually involved the entire hand and caused functional

512 limitations of digital flexion and extension; only mild local pain was

513 noted. Note the significant local edema of the thenar eminence in

514 Panel B (images courtesy of Tyrone Ping).

515
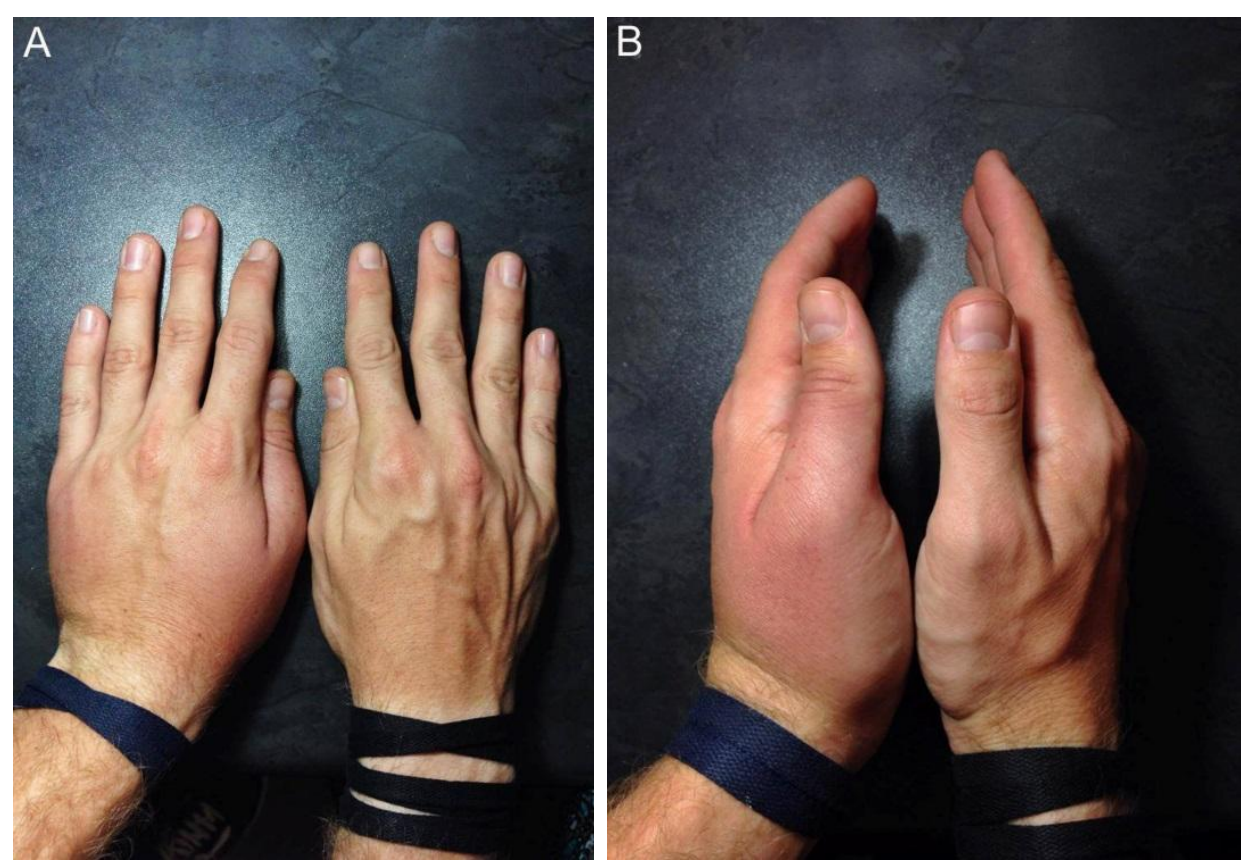